\title{
Test of validity of a dynamic soil carbon model using data from leaf litter decomposition in a West African tropical forest
}

G. H. S. Guendehou ${ }^{1,2}$, J. Liski ${ }^{3}$, M. Tuomi ${ }^{3}$, M. Moudachirou ${ }^{4}$, B. Sinsin ${ }^{5}$, and R. Mäkipää ${ }^{2}$

${ }^{1}$ Centre Béninois de la Recherche Scientifique et Technique, 03 BP 1665 Cotonou, Bénin

${ }^{2}$ Finnish Forest Research Institute, P.O. Box 18, 01301 Vantaa, Finland

${ }^{3}$ Finnish Environment Institute, P.O. Box 140, 00251 Helsinki, Finland

${ }^{4}$ Laboratoire de Pharmacognosie, Faculté des Sciences et Techniques, Université d'Abomey-Calavi, 01 BP 918 Cotonou, Bénin

${ }^{5}$ Laboratoire d'Ecologie Appliquée, Faculté des Sciences Agronomiques, Université d'Abomey-Calavi, 01 BP 526 Cotonou, Bénin

Received: 8 April 2013 - Accepted: 6 May 2013 - Published: 28 May 2013

Correspondence to: G. H. S. Guendehou (sabin.guendehou@metla.fi, sguendehou@yahoo.com)

Published by Copernicus Publications on behalf of the European Geosciences Union.

Soil carbon

modeling in tropical

forests

G. H. S. Guendehou et al.

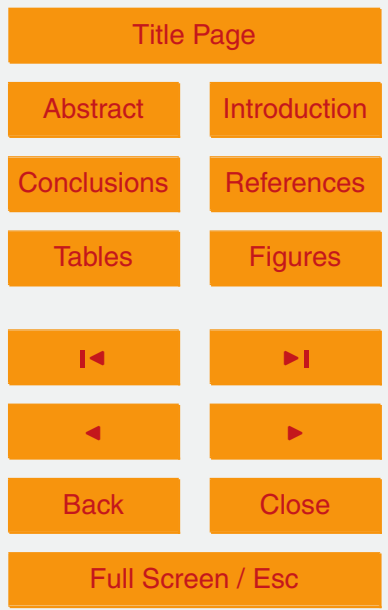

Printer-friendly Version

Interactive Discussion 


\section{Abstract}

We evaluated the applicability of the dynamic soil carbon model Yasso07 in tropical conditions in West Africa by simulating the litter decomposition process using as required input into the model litter mass, litter quality, temperature and precipitation col5 lected during a litterbag experiment. The experiment was conducted over a six-month period on leaf litter of five dominant tree species, namely Afzelia africana, Anogeissus leiocarpa, Ceiba pentandra, Dialium guineense and Diospyros mespiliformis in a semideciduous vertisol forest in Southern Benin. Since the predictions of Yasso07 were not consistent with the observations on mass loss and chemical composition of litter, 10 Yasso07 was fitted to the dataset composed of global data and the new experimental data from Benin. The re-parameterized versions of Yasso07 had a good predictive ability and refined the applicability of the model in Benin to estimate soil carbon stocks, its changes and $\mathrm{CO}_{2}$ emissions from heterotrophic respiration as main outputs of the model. The findings of this research support the hypothesis that the high variation of 15 litter quality observed in the tropics is a major driver of the decomposition and needs to be accounted in the model parameterization.

\section{Introduction}

In tropical conditions in Africa, little attention has been paid to litter decomposition and quantification of changes in the soil organic carbon (SOC), though forest soil in this region accounts for $11 \%$ of the world's soil carbon pool (FAO, 2010). Quantification of SOC dynamics in tropical Africa is required to improve the estimation of the global carbon balance. The SOC changes are reported under the Climate Change Convention as a part of the national greenhouse gas inventories of the forestry sector (UNFCCC, 2008,2010 ), but majority of the countries in tropical Africa either report no changes in SOC stocks or apply default stock change factors of the Intergovernmental Panel on Climate Change methodologies (par ex. IPCC, 2003, 2006) together with rough
Soil carbon

modeling in tropical

forests

G. H. S. Guendehou et al.

Title Page

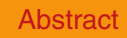

Introduction

Conclusions

Tables

References

Figures

14

$\rightarrow$

4

Back

Close

\section{Full Screen / Esc}

Printer-friendly Version

Interactive Discussion 
estimation of the land use and land use change. Under the United Nations Framework Convention on Climate Change (UNFCCC) mechanism of the Reducing Emissions from Deforestation and Forest Degradation in Developing Countries (REDD), the countries have economic incentives for the conservation, the sustainable management and 5 the enhancement of their forest carbon stocks and robust methods leading to confident and verified carbon stock estimates are increasingly required. A number of studies have reported SOC stocks estimated from only sporadic soil sampling and digital maps (for example Manu et al., 1991; Prudencio, 1993; Volkoff et al., 1999; Henry et al., 2009) and the reported values in the existing databases in Africa (Batjes, 1996, 2002, 2005, 10 2006; FAO, 2008) consist of global estimates with limited indications on changes and distribution according to ecosystems.

The dynamics of SOC is influenced by litter quantity and quality, climate and metabolism of decomposing organisms and governed by other physical, chemical and biological factors, such as soil properties, which all may be difficult to quantify (Swift and Anderson, 1989; Aerts, 1997; Coûteaux et al., 1998; Lavelle et al., 1993). Overall changes in the SOC stock may be quantified with measurements, but repeated measurements of soil carbon stocks are laborious, time and resources consuming efforts with the added drawback of the difficulty of predicting future levels. Also, extrapolating only a few SOC measurements to a large scale may lead to high uncertainty due to the spatial variation of SOC. Thus, processes taking place in soil and SOC stock changes are studied mostly through the use of decomposition models (Coleman and Jenkinson, 1996; Currie and Aber, 1997; Kurz and Apps, 1999; Chertov et al., 2001; Liski et al., 2005; Sierra et al., 2012). The application of the model-based approach could also help countries to meet SOC reporting requirements in tropical Africa, where resources are limited. However, model results and their applicability depend on model structure and parameters, as well as on available input information and assumptions used (Peltoniemi et al., 2007; Palosuo et al., 2012).

To our knowledge, no SOC model calibrated using litter decomposition data from forests in Africa is available. The litter quality is known to be the most important
GMDD

Soil carbon

modeling in tropical forests

G. H. S. Guendehou et al. Title Page
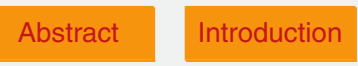

Conclusions

Tables

References

Figures

14

$\rightarrow$

4

Back

Close

\section{Full Screen / Esc}

Printer-friendly Version

Interactive Discussion 
determinant of the decomposition rate at regional scale (e.g. Tian et al., 1992; Berg et al., 1993; Lavelle et al., 1993; Aerts, 1997; Loranger et al., 2002; Guendehou et al., 2014) and the plant species richness of tropical forests yields high variation in the litter quality (Goma-Tchimbakala and Bernhard-Reversat, 2006; Barbhuiya et al., 2008; 5 Cusack et al., 2009). However, only a few litter types from tropical tree species were included in the dataset that was used for the parameterization of the widely applied soil carbon model (Coleman and Jenkinson, 1996; Chertov et al. 2001; Tuomi et al., 2009) and many soil models are parameterized only for temperate and boreal conditions.

In this paper, we assessed the applicability of the dynamic soil carbon model 10 Yasso07 in tropical conditions in West Africa, by simulating the litter decomposition process using data on litter mass, litter quality, temperature and precipitation. The data was collected from a litterbag experiment conducted on leaf litter from five dominant tree species, namely Afzelia africana, Anogeissus leiocarpa, Ceiba pentandra, Dialium guineense, and Diospyros mespiliformis, in the natural semi-deciduous forest Lama in 15 Southern Benin. We tested the hypotheses that the decomposition process in tropics is affected by the high variation of litter quality and re-parameterization of the Yasso07 model with the diverse litter data from tropics improves the precision of the mass loss predictions.

\section{Material and methods}

\subsection{Experimental site}

The experimental site is the Lama forest, a natural semi-deciduous forest located in a humid tropical climate in Southern Benin (Nagel et al., 2004) at $6^{\circ} 55^{\prime}-7^{\circ} 00^{\prime} \mathrm{N}, 2^{\circ} 04^{\prime}-$ $2^{\circ} 12^{\prime} \mathrm{E}$ (Fig. 1). The site falls within the tropical moist zone according to the classification scheme for climate regions of the IPCC (IPCC, 2006). The highest $\left(38^{\circ} \mathrm{C}\right)$ and the lowest $\left(15^{\circ} \mathrm{C}\right)$ temperatures were usually recorded in February-March and in December, respectively. The mean annual temperature is $27^{\circ} \mathrm{C}$. The precipitation shows
GMDD

6, 3003-3032, 2013

Soil carbon

modeling in tropical

forests

G. H. S. Guendehou et al.

Title Page

Abstract

Introduction

Conclusions

Tables

References

Figures

14

$\rightarrow$ I

4

Back

Close

Printer-friendly Version

Interactive Discussion 
a bimodal distribution pattern. The mean annual precipitation in the experimental site is $1100 \mathrm{~mm}$; rainfall is, in general, more than $100 \mathrm{mmmonth}^{-1}$ throughout the year, except in January, February and December. Years are divided into four seasons: two rainy and two dry seasons. The principal rainy season occurs between mid-March and 5 mid-July and the shorter rainy season between mid-September and mid-November. The monthly average of relative humidity is always more than $51 \%$. Table 1 shows the monthly climatic data recorded by the national meteorological service at the time of the decomposition experiment.

The soil of the Lama forest is reported as a rare hydromorphic clayey vertisol (40 to 10 $60 \%$ of clay) in West Africa, with a poor drainage and a $\mathrm{pH}$ range of 5-5.5 in the 0$30 \mathrm{~cm}$ horizon (Küppers et al., 1998). The $\mathrm{pH}$ increases up to 6.5-7 in deeper horizons due to the appearance of limestone at a depth of $150 \mathrm{~cm}$. This soil has been described as rich in calcium $(\mathrm{Ca})$ and magnesium $(\mathrm{Mg})$ due to a "granito-gneissic" parent material from the secondary and tertiary ages. The mean altitude in the forest is $60 \mathrm{~m}$ (von Bothmer et al., 1986).

The tree species richness of the Lama forest was described by Akoègninou (1984), Mondjannagni (1969), Paradis and Houngnon (1977). Küppers et al. (1998) reported 67 families based on an inventory carried out in 1998. The average density in the natural dense part of the forest where the experiment took place is $12 \mathrm{species} / 400 \mathrm{~m}^{2}$, and the relative abundance of dominant tree species is about 40 trees $/ 400 \mathrm{~m}^{2}$ (Küppers et al., 1998). The current research focused on five dominant tree species including $A$. africana, A. leiocarpa, C. pentandra, D. guineense and D. mespiliformis (von Bothmer et al., 1986; Küppers et al., 1998; Nagel et al., 2004). No human activities such as harvesting or fertilization are implemented in the experimental site. In Lama forest, the

amount of leaf litter fall ranges from 26 to $42 \mathrm{t}$ dry matter $\mathrm{yr}^{-1}$; the litter fall follows a unimodal distribution pattern, with the maximum litter production observed during the dry season, often in January (Djego, 2006).
GMDD

Soil carbon

modeling in tropical forests

G. H. S. Guendehou et al.

Title Page

Abstract Introduction

Conclusions

Tables References Figures

14 $\rightarrow$

4

Back

Close

\section{Full Screen / Esc}

Printer-friendly Version

Interactive Discussion 


\subsection{Litterbag experiment, mass loss measurement, and chemical analyses}

The material used consisted of leaf litter of $A$. africana, $A$. leiocarpa, $C$. pentandra, $D$. guineense, and $D$. mespiliformis. Only senescent leaves ready to fall from the trees were collected. Leaves were dried in open-air and then oven-dried at $75^{\circ} \mathrm{C}$ to constant

5 weight. In order to use all the amount of litter collected, an initial mass of dried leaves of $A$. africana $(20 \mathrm{~g})$, A. leiocarpa $(30 \mathrm{~g})$, C. pentandra $(20 \mathrm{~g})$, D. guineense $(30 \mathrm{~g})$, and D. mespiliformis $(30 \mathrm{~g})$ was placed in the litterbags in polyester $(20 \mathrm{~cm} \times 20 \mathrm{~cm}$, mesh size $0.33 \mathrm{~mm}$ ) on the forest floor. Litterbags were divided between four plots established in a nearly rectangular configuration; the distance between the plots (between

25 and $30 \mathrm{~m}$ ) was assumed large enough to minimize the spatial autocorrelation between plots. In each plot, litterbags were placed in rows and columns on the forest floor: there were five columns each containing the five litter species and six rows each containing the six collections. In total, 30 litterbags were placed in a plot. In each row, the five bags were placed. Bags were not moved until collection date and no disturbances occurred during the experiment. Bags were collected every four weeks from the four plots (between February and July 2010), the remaining litter was dried in open air and in the oven at $75^{\circ} \mathrm{C}$ to constant weight. The remaining mass was measured and the mass loss estimated. The remaining dried litter was kept in a freezer in a plastic bag before the chemical analyses.

20 The chemical analyses on litter prior to decomposition and on decomposed litter were carried out in the laboratory of the Finnish Forest Research Institute. Based on the solubility difference of the essential constituents of leaf litter in different solvents, the analyses enabled to determine the concentration of compounds soluble in ethanol, compounds soluble in water, compounds hydrolysable in acid, and compounds neiconducted in a sonicating water bath, first for $90 \mathrm{~min}$ with ethanol, then for $90 \mathrm{~min}$ with water (Karhu et al., 2010). The ethanol- and water extracted residue was divided into acid-hydrolysable $\left(72 \% \mathrm{H}_{2} \mathrm{SO}_{4}\right)$ and non-hydrolysable fractions using the Klason lignin
Soil carbon

modeling in tropical forests

G. H. S. Guendehou et al. Title Page
Abstract

Conclusions

Tables

14

4

Back

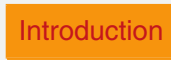

References

Figures

-1
Close

\section{Full Screen / Esc}

Printer-friendly Version

Interactive Discussion 
method (Effland, 1977). Samples were filtered, oven-dried at $75^{\circ} \mathrm{C}$ to constant weight and weighed between the extractions, and the amounts of different fractions were determined as proportions of the mass of organic matter. The ash content of the samples was determined after keeping the dried samples in a muffle furnace at $550^{\circ} \mathrm{C}$ overnight. Due to the high number of chemical parameters to determine on each collected samples (160 parameters), samples of the same litter species and same collection were pooled for chemical analyses in order to reduce the amount of work, and assuming this yields the average chemical composition of the four plots.

\subsection{Model description, simulations of litter decomposition process and data analysis}

In the model Yasso07, fresh organic matter in leaf, fine root, and woody litter is divided into four chemically distinguishable compound groups: acid-hydrolysable compounds $(A)$, water-soluble compounds (W), ethanol-soluble compounds $(E)$, neither soluble, nor hydrolysable compounds $(\mathrm{N})$ that decompose at their unique rates (Tuomi et al., 2009). In addition, there is a humus $(H)$ fraction, assumed to consist of more recalcitrant compounds, that receives a part of products resulting from the decomposition of $A, W$, $\mathrm{E}, \mathrm{N}$ (Fig. 2). The decay rates (as measure of microbial activity) of the compound groups depend on the climatic conditions described by temperature and precipitation (Meentemeyer, 1978; Berg et al., 1993; Aerts, 1997; Liski et al., 2003; Parton et al., 2007). The decomposition of compound groups results in mass loss from the system and in mass flows between the compound groups. The mass loss consists of removal from the soil as heterotrophic respiration $\left(\mathrm{CO}_{2}\right)$ and leaching while the remaining mass forms more recalcitrant compounds, for example humus.

Mathematically, Yasso07 is a linear compartmental system, a set of first order differ-

$$
\dot{\boldsymbol{x}}(t)=\mathbf{A}(C) \boldsymbol{x}(t)+\boldsymbol{b}(t)-\omega_{i} I P_{\mathrm{a}}, \quad \boldsymbol{x}(0)=\boldsymbol{x}_{0}
$$

GMDD

6, 3003-3032, 2013

Soil carbon

modeling in tropical

forests

G. H. S. Guendehou et al.

Title Page

Abstract

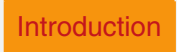

Conclusions

Tables

References

Figures

14

$\rightarrow$

4

Back

Close

Printer-friendly Version

Interactive Discussion 
where $\boldsymbol{x}=\left(x_{\mathrm{A}}, x_{\mathrm{W}}, x_{\mathrm{E}}, x_{\mathrm{N}}, x_{\mathrm{H}}\right)^{\top}$ is a vector describing the masses of the five compartments as a function of time $(t) ; \mathbf{A}(C)$ is a matrix describing the decomposition rates and the mass flows between the compartments as a function of climatic conditions $(C)$; vector $\boldsymbol{b}(t)$ is the litter input to the soil; $\omega_{i}$ are free parameters describing the precipitation

5 induced leaching rates; $I=(1,1,1,1,1)^{\top}$ is a constant column vector; $P_{\mathrm{a}}$ is the annual precipitation. Vector $x_{0}=\left(x_{\mathrm{A}, 0}, x_{\mathrm{W}, 0}, x_{\mathrm{E}, 0}, x_{\mathrm{N}, 0}, x_{\mathrm{H}, 0}\right)$ describes the initial chemical composition state of the system. Matrix $\mathbf{A}$ is defined as a product of the mass flow matrix $\mathbf{A}_{\mathrm{p}}$ and the diagonal decomposition coefficient matrix $\mathbf{k}(C)=\operatorname{diag}\left(k_{\mathrm{A}}, k_{\mathrm{W}}, k_{\mathrm{E}}, k_{\mathrm{N}}, k_{\mathrm{H}}\right)(C)$, where $k_{i}$ are the decomposition rate coefficients of the compartments (Tuomi et al., 2009).

$\mathbf{A}_{\mathrm{p}}=\left(\begin{array}{ccccc}-1 & p_{1} & p_{2} & p_{3} & 0 \\ p_{4} & -1 & p_{5} & p_{6} & 0 \\ p_{7} & p_{8} & -1 & p_{9} & 0 \\ p_{10} & p_{11} & p_{12} & -1 & 0 \\ p_{\mathrm{H}} & p_{\mathrm{H}} & p_{\mathrm{H}} & p_{\mathrm{H}} & -1\end{array}\right)$

Title Page

where $p_{i} \in[0,1]$ are relative mass flow parameters between the compartments. $p_{1} \therefore$ relative mass flow magnitude, $\mathrm{W} \rightarrow \mathrm{A} ; p_{2}$ : relative mass flow magnitude, $\mathrm{E} \rightarrow \mathrm{A}$; $p_{3}:$ relative mass flow magnitude, $\mathrm{N} \rightarrow \mathrm{A} ; p_{4}$ : relative mass flow magnitude, $\mathrm{A} \rightarrow \mathrm{W}$; $15 p_{5}:$ relative mass flow magnitude, $\mathrm{E} \rightarrow \mathrm{W} ; p_{6}$ : relative mass flow magnitude, $\mathrm{N} \rightarrow \mathrm{W}$; $p_{7}:$ relative mass flow magnitude, $\mathrm{A} \rightarrow \mathrm{E} ; p_{8}$ : relative mass flow magnitude, $\mathrm{W} \rightarrow \mathrm{E}$; $p_{9}:$ relative mass flow magnitude, $\mathrm{N} \rightarrow \mathrm{E} ; p_{10}$ : relative mass flow magnitude, $\mathrm{A} \rightarrow \mathrm{N}$; $p_{11}:$ relative mass flow magnitude, $\mathrm{W} \rightarrow \mathrm{N} ; p_{12}$ : relative mass flow magnitude, $\mathrm{E} \rightarrow \mathrm{N}$; $p_{\mathrm{H}}:$ mass flow to humus.

Soil carbon

modeling in tropical

forests

G. H. S. Guendehou et al.

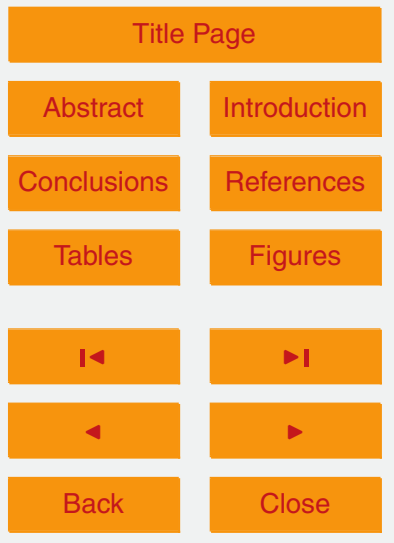

Full Screen / Esc

Printer-friendly Version

Interactive Discussion 
The climate dependence of the decomposition rate factors $k_{i}$ formulated in Eq. (2) was justified earlier by Tuomi et al. (2009):

$k_{i}(C)=\alpha_{i} \exp \left(\beta_{1} T+\beta_{2} T^{2}\right)\left(1-\exp \left[\gamma P_{\mathrm{a}}\right]\right)$

where $T$ is temperature (Celsius scale), $P_{\mathrm{a}}$ : annual precipitation, $\alpha_{i}$ : decomposition 5 rate parameter, $\beta_{1}$ and $\beta_{2}$ : temperature dependence parameters, $\gamma$ : precipitation dependence parameter. $\alpha_{i}, \beta_{1}, \beta_{2}$, and $\gamma$ are free parameters.

The structure and mathematical formulas of Yasso07 are described in more detail in previous publications (Tuomi et al., 2009, 2011a).

The data needed to run the model Yasso07 include: litter amount, litter quality (dis-

\section{standard deviations) and climatic data (temperature and precipitation).}

The simulation was conducted on each individual studied litter species. An initial mass of litter with its chemical composition (Figs. 3-7) and climatic data (Table 1) were used as inputs into the dynamic soil carbon model Yasso07. The predictions of Yasso07

15 were compared with the observations on change in mass, and change in chemical composition. Then, Yasso07 was fitted to a dataset where new data from Benin were merged with a global data (from Europe; Berg et al., 1991a,b, 1993, Northern and Central America, Gholz et al., 2000; Trofymow et al., 1998). Also, Yasso07 was fitted only to the new experimental data from Benin. This resulted in two new versions of 20 the Yasso07: Y07A to refer to Yasso07 fitted to the dataset including global and Benin data, and Y07B to refer to Yasso07 fitted only to new data from Benin. The predictions of these two versions were compared with the observations using mean residuals and standard deviations thereof.

When analysing the data, the Bayesian inference of information from the measurements to the parameter values (see for example, Ellison, 2004) was used. Following the method of Tuomi et al. $(2009,2011 a)$, the Markov chain Monte Carlo (MCMC) posterior sampling technique was used in data analyses. The reason for selecting this method was its ability to produce a sample from the posterior probability density of the model 3011
GMDD

6, 3003-3032, 2013

Soil carbon

modeling in tropical

forests

G. H. S. Guendehou et al.

Title Page

Abstract

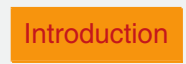

Conclusions

Tables

References

Figures

14

$\rightarrow 1$

4

Back

Close

Printer-friendly Version

Interactive Discussion 
parameters in relation to the measurements and to converge to the global probability maximum in the parameter space. As a result, any point and uncertainty estimates are readily available from the analyses. Particularly, we used the adaptive Metropolis algorithm of Haario et al. (2001), which is an improved version of the famous Metropolis 5 Hastings sampling algorithm (Hastings, 1970; Metropolis et al., 1953). The adaptive Metropolis algorithm is known to work well in similar analysis problems (for example, Malve et al., 2007). Almost all of the parameters were found to have close to Gaussian distributions. Therefore, the distributions are described using two common numbers, namely, the maximum a posteriori (MAP) point estimates and standard deviations as 10 uncertainty estimates. These estimates were calculated for both Y07A and Y07B. The $95 \%$ confidence limits are thus 1.96 times the standard deviations (Table 2).

\section{Results}

The litter qualities of species studied in this research differed in terms of their initial chemical fractions (Figs. 4-7). The variation in chemical fractions across species 15 was more pronounced in ethanol-soluble, water-soluble, Klason lignin than in acidhydrolysable. The litters were richer in acid-hydrolysable than other chemical fractions.

The predictive ability of the original version of Yasso07 (Y07 software) was found inadequate for mass loss of any studied litter species (Fig. 3). This original version overestimated the total remaining mass in all decomposed litter by 18 to $230 \%$. It did not indicate the rapid decrease in mass loss observed during the early stages of decomposition (for example the first eight weeks). It overestimated the remaining mass of acid-hydrolysable compounds and ethanol-soluble compounds. The predicted remaining mass of water-soluble compounds was rather similar to the measurements. With regard to Klason lignin, the remaining mass was overestimated in $A$. africana throughout the time-series, while in the other litter species, the software underestimated the remaining mass at early stages and thereafter overestimated it (after 0.2 to $0.3 \mathrm{yr}$ ) (Figs. 4-7).

Soil carbon

modeling in tropical forests

G. H. S. Guendehou et al. Title Page

\section{Abstract}

Conclusions

Tables

14

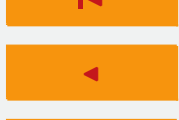

Back

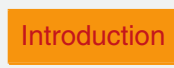

References

Figures

$\rightarrow$

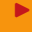

Close

\section{Full Screen / Esc}

Printer-friendly Version

Interactive Discussion 
A version where new data from tropics was also used in the parameterisation (Y07A version) appeared to be good in predicting the mass loss. The predicted total remaining mass was similar to the measurements on average, although it was overestimated in $A$. africana and underestimated in $D$. mespiliformis. However, the predicted differ5 ences were not remarkable. The residuals for Y07A range from -0.18 to $0.21 \mathrm{gg}^{-1}$ initial organic matter (Fig. 3). The remaining mass of acid-hydrolysable compounds predicted by Y07A was similar to the measurements. The error corrected compared to Y07 software was related to the mass flow from the water-soluble compartment to the acid-hydrolysable compartment (Table 2). The remaining mass of water-soluble o compounds were consistent with the measurements, and decreased faster. Y07A still overestimated slightly the remaining mass of ethanol-soluble compounds. With regard to Klason lignin, the predicted remaining mass followed the measurements, although it was slightly underestimated in $D$. mespiliformis. The reasons, as reflected in Table 2, are increased in mass flow from water-soluble compartment to Klason lignin compart15 ment and higher decomposition coefficient of Klason lignin.

Y07B also appeared to be good in predicting the mass loss. The residuals for Y07B ranged from -0.21 to $0.21 \mathrm{gg}^{-1}$ initial organic matter (Fig. 3). The predicted remaining mass of ethanol-soluble compounds were closer to the measurements due to the high decomposition coefficient. Also, the remaining mass of Klason lignin was close to the measurements (despite low mass flow from water-soluble compartment to Klason lignin compartment); this was explained by the high decomposition coefficient of ethanolsoluble compounds and the large mass flow from ethanol-soluble to Klason lignin.

The decomposition rates of chemical fractions $(A, W, E$, and $N)$ were substantially higher when determined from the Benin data only (Table 2). Especially the $E$ fraction had almost as high decomposition rate as the $\mathrm{W}$ fraction, whereas this fraction had the second lowest decomposition rate when determined from all data. The mass flows had comparable values regardless of being determined from the Benin data or all data. However, the mass flows from $N$ to $W, W$ to $E$, and $A$ to $E$ were considerably higher based on Benin data. In addition, the parameter describing the mass flow from $\mathrm{W}$ to $\mathrm{N}$
GMDD

6, 3003-3032, 2013

Soil carbon

modeling in tropical

forests

G. H. S. Guendehou et al.

Title Page

Abstract

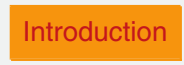

Conclusions

Tables

References

Figures

14

-1

4

Back

Close

\section{Full Screen / Esc}

Printer-friendly Version

Interactive Discussion 
had a substantially lower value based on the Benin data. Also, parameter describing leaching rate in Benin had a greater value when determined from all data.

The parameter values of Benin were used to develop a user-interface version of Yasso07 for Benin (software available from www.syke.fi/projects/yasso).

\section{Discussion}

The litter quality of species studied differed from the litter quality of Drypetes glauca (Gholz et al., 2000) the only tropical tree species whose data on litter quality (leaf, fine root) were used together with data from other climatic regions to initially parameterize Yasso07 (Tuomi et al., 2009). The greatest differences among the litters 10 were the high initial water-soluble concentration $\left(402.3 \mathrm{mg} \mathrm{g}^{-1}\right)$, the low initial concentration of ethanol-soluble $\left(80.2 \mathrm{mg} \mathrm{g}^{-1}\right)$, acid-hydrolysable $\left(398.2 \mathrm{mg} \mathrm{g}^{-1}\right)$, and Klason lignin $\left(109.1 \mathrm{mg} \mathrm{g}^{-1}\right)$ of the Drypetes glauca leaves. Earlier studies conducted in India, South America and Africa (Goma-Tchimbakala and Bernhard-Reversat, 2006; Barbhuiya et al., 2008; Cusack et al., 2009) also reported large interspecies variation in the 15 initial litter chemical fractions.

The fact that Yasso07 did not perform well in predicting litter mass loss and chemical composition in this study could be justified by the fact that Yasso07 was calibrated using data on leaf litter, fine root, and climate from only five sites in the tropics located in Central America and considering only Drypetes glauca (Tuomi et al., 2009). The 20 Yasso07 model accounted for climatic variation as the model incorporated decomposition data from a wide range of climatic conditions, but the variation of the litter quality in tropics was not incorporated. In tropical forests of West Africa, the use of Yasso07 in its original version would lead to an underestimation of the decomposition rate and thus to a higher soil carbon stock than that observed.

The litter decomposition data from semi-deciduous forest in Benin indicated that there may not be a significant mass flow from water-soluble compartment to acidhydrolysable compartment, like there is in the Y07 version. They also indicated that
GMDD

6, 3003-3032, 2013

Soil carbon

modeling in tropical

forests

G. H. S. Guendehou et al.

Title Page

Abstract

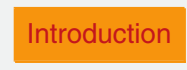

Conclusions

Tables

References

Figures

14

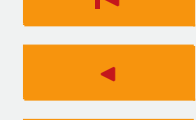

$\rightarrow 1$

Back

Close

Full Screen / Esc

Printer-friendly Version

Interactive Discussion 
Klason lignin fraction is formed faster and decomposed faster than in the Y07 version. However, it is not clear from which fraction the Klason lignin fraction is formed. According to Y07A, there is large flow from both water-soluble and ethanol-soluble fractions; according to Y07B, the large flow is from ethanol-soluble fraction. However, the expla5 nation from chemical point of view of this large mass flow from ethanol-soluble to Klason lignin remains a question. It is likely that simple components, easily decomposable, for example waxes, ethanol-soluble, become resistant or give resistant products during the process. Ethanol-soluble fraction decomposes faster than in the Y07 version. The new litter decomposition data from tropical climate helped to understand where 10 the problems of the model are, especially with regard to its applicability outside the data domain for which it was developed. This new information will help to improve the model also in future. Furthermore, given that data on litter decomposition is becoming available in the tropics (Goma-Tchimbakala and Bernhard-Reversat, 2006; Barbhuiya et al., 2008; Cusack et al., 2009; Meng et al., 2011; Tynsong and Tiwari, 2011), Yasso07 needs to be recalibrated to take into account the wide range of litter quality in order to refine the applicability of the model in tropical conditions.

Y07A and Y07B appear to predict the mass loss very well, and the fact that both adjusted model versions performed in a similar way implies that Y07A could accurately predict mass loss in tropical conditions. The level of decomposition rate predicted with Y07B was higher in Benin, but the major pathways of the decomposition process (mass flows between chemical compound groups) were rather similar for Y07A and Y07B. These summary observations support the structure of the model and emphasize the need to understand more clearly the factors affecting the decomposition rate. Given that the decomposition of soil organic matter occurs more rapidly in the tropics than in the temperate areas (Six et al., 2002; Krull et al., 2002) and that humus is formed only after a long-term decomposition process of litter (Berg, 2000), the formation of humus is unlikely to occur in a decomposition experiment conducted over a six-months period. Only decomposing organic matter was measured during this period. Therefore

Soil carbon

modeling in tropical forests

G. H. S. Guendehou et al.

Title Page
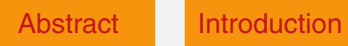

Conclusions References

Tables Figures

14 $\rightarrow 1$

4

Back

Close

Full Screen / Esc

Printer-friendly Version

Interactive Discussion 
the model simulation did not include the humus compartment, and there were no parameter values for humus in Table 2 (for e.g. relative mass flow to humus).

The type of litterbag has also an effect on the mass loss rate. It is necessary to understand these effects of litterbags to get a more profound understanding on which 5 part of differences may be attributable to the litterbag and which to actual differences in the decomposition process. The difference in the litter bag mesh size resulted in different leaching rates of organic matter out of the bags. We modelled this leaching as in Tuomi et al. (2011b). The leaching rates in the Americas and in Europe were found to differ from one another, but they also differ from the one apparent from the Benin mass loss data, because all three sets of experiments used litter bags with different mesh sizes. The mesh sizes were 1.0, 0.055, and $0.33 \mathrm{~mm}$ for the European, American, and Beninese litter bags, respectively. For Y07A, the mass loss in Benin was found to occur relatively fast, which resulted in a large value for the leaching rate parameter, $\omega_{\mathrm{B}}$ (Table 2). This high value of leaching rate in Benin accounted for the high mass loss measured in Benin. Conversely, when only fitting the model parameters to Benin data in Y07B, the leaching rate was found lower, but the rapid mass loss in Benin resulted in a faster decomposition, as seen in the parameter values of Table 2. In the context of Y07A, we interpret these differences as arising from the high leaching rate in Beninese data $\left(0.94 \mathrm{yr}^{-1} \mathrm{~m}^{-1}\right)$ caused by the combination of large mesh size in the Beninese litter bags and the high annual precipitation in the Beninese site of $1604 \mathrm{~mm}$. In the set of parameter values determined from the Benin data only, the high mass loss were attributable to the decomposition process (high decomposition rates). The leaching rate is negligible in the American data because of the small mesh size $(0.055 \mathrm{~mm})$ and lower in the European data because of the much lower annual precipitation in the European sites (Tuomi et al., 2009).

Soil carbon

modeling in tropical forests

G. H. S. Guendehou et al. Title Page
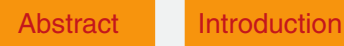

Conclusions

Tables

References

Figures

14

$\rightarrow$

4

Back

Close

Printer-friendly Version

Interactive Discussion 


\section{Conclusions}

This study provides evidence that the soil carbon model Yasso07 did not incorporate the chemical diversity of tropical litters, even if the climatic variation was accounted for in the structure of the model, and demonstrates that the model can be refined by 5 integrating available data from the tropics.

New parameterisation of Yasso07, using data from Benin together with global data, resulted in model predictions consistent with the mass loss measurements and chemical composition of the litter bag experiment. This Yasso07 version is suitable for estimating carbon stocks, change in carbon stocks, and $\mathrm{CO}_{2}$ emissions from forest soils in Benin.

All data indicated that more complex compounds are broken down during the decomposition process following the path: Klason lignin - acid-hydrolysable - water-soluble - carbon dioxide.

This paper is an example of a test of validity and revision of a dynamic soil carbon model in tropical conditions. It will facilitate the assessment of the contribution of soil carbon pool in Africa to the global carbon cycle and the transition from the use of the default method and assumption from the IPCC to using higher tier method to report to the UNFCCC (for example, national inventories, the REDD mechanism). However, in order to improve the completeness of the reporting, future research should cover all litter species and litter types other than leaf from the whole range of remaining tree species existing in Benin.

Acknowledgements. This work is supported by a scholarship from "Commission Nationale d'Attribution de Bourses de Stages du Bénin" (National Committee of Scholarship of Benin). We would like to thank "Conseil Scientifique de l'Université d'Abomey Calavi du Bénin", "Office 25 National du Bois du Bénin", Riitta Pipatti at Statistics Finland, and Jari Varjo and Pasi Puttonen at the Finnish Forest Research Institute.
Soil carbon

modeling in tropical

forests

G. H. S. Guendehou et al.

Title Page

Abstract

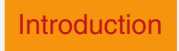

Conclusions

Tables

References

Figures

14

$\rightarrow 1$

4

Back

Close

\section{Full Screen / Esc}

Printer-friendly Version

Interactive Discussion 


\section{References}

Aerts, R.: Climate, leaf litter chemistry and leaf litter decomposition in terrestrial ecosystems: a triangular relationship, Oikos, 79, 439-449, 1997.

Akoègninou, A. : Contribution à l'étude botanique des îlots de forêts denses humides semidécidues en République Populaire du Bénin, Thèse de doctorat, Université de Bordeaux III, 1984.

Barbhuiya, A. R., Arunachalam, A., Nath, P. C., Khan, M. L., and Arunachalam. K: Leaf litter decomposition of dominant tree species of Namdapha national park, Arunachal Pradesh, northeast India, J. Forest Res.-Jpn., 13, 25-34, 2008.

Batjes, N. H.: Total carbon and nitrogen in the soils of the world, Eur. J. Soil Sci., 47, 151-163, 1996.

Batjes, N. H.: Soil parameters estimates for the soil types of the world for use in global and regional modelling (Version 2.1, July 2002), ISCRI report 2002/02c, International Food Policy Research Institute (IFPRI), International Soil Reference and Information Centre (ISRIC),

15 Wageningen, 52, 2002.

Batjes, N. H.: ISRIC-WISE global data set of derived soil properties on a 0.5 by 0.5 degree grid (Version 3.0), Report 2005/08, ISRIC-World Soil Information, Wageningen, 24, 2005.

Batjes, N. H.: ISRIC-WISE derived soil properties on a 5 by 5 arc-minutes global grids, Report 2006/02, available at: http://www.isric.org (last access: October 2012), ISRIC-World Soil Information, Wageningen, 2006.

Berg, B.: Litter decomposition and organic matter turnover in northern forest soils, Forest Ecol. Manag., 133, 13-22, 2000.

Berg, B., Booltink, H., Breymeyer, A., Ewertsson, A., Gallardo, A., Holm, B., Johansson, M.B., Koivuoja, S., Meentemeyer, V., Nyman, P., Olofsson, J., Pettersson, A. S., Reurslag, A., Staaf, H., Staaf, I., and Uba, L.: Data on needle litter decomposition and soil climate as well as site characteristics for some coniferous forest sites, Part I, Site characteristics, Report 41, Swedish University of Agricultural Sciences, Department of Ecology and Environmental Research, Uppsala, 1991a.

Berg, B., Booltink, H., Breymeyer, A., Ewertsson, A., Gallardo, A., Holm, B., Johansson, M. B., Staaf, H., Staaf, I., and Uba, L.: Data on needle litter decomposition and soil climate as well as site characteristics for some coniferous forest sites, Part II, Decomposition data, Report

Soil carbon

modeling in tropical

forests

G. H. S. Guendehou et al.

Title Page

Abstract

Introduction

Conclusions

References

Tables

Figures

14

$\rightarrow$

4

Back

Close

\section{Full Screen / Esc}

Printer-friendly Version

Interactive Discussion 
42, Swedish University of Agricultural Sciences, Department of Ecology and Environmental Research, Uppsala, 1991b.

Berg, B., Berg, M. P., Bottner, P., Box, E., Breymeyer, A., De Anta, R. C., Couteaux, M., Mälkönen, E., McClaugherty, C., Meentemeyer, V., Munoz, F., Piussi, P., Remacle, J., and De

5 Santo, A. V.: Litter mass loss in pine forests of Europe and Eastern United States: some relationships with climate and litter quality, Biogeochemistry, 20, 127-159, 1993.

Chertov, O. G., Komarov, A. S., Nadporozhskaya, M., Bykhovets, S. S., and Zudin, S. L.: ROMUL - a model of forest soil organic matter dynamics as a substantial tool for forest ecosystem modeling, Ecol. Model., 138, 289-308, 2001.

10 Coleman, K. and Jenkinson, D. S.: RothC-26.3 - a model for the turnover of carbon in soil, in: Evaluation of Soil Organic Matter Models, Using Existing Long-Term Datasets, edited by: Powlson, D. S., Smith, P., and Smith, J. U., Springer, Heidelberg, 237-246, 1996.

Coûteaux, M. M., McTiernan, K., Berg, B., Szuberla, D., and Dardennes, P.: Chemical composition and carbon mineralisation potential of Scots pine needles at different stages of decom-

15 position, Soil Biol. Biochem., 30, 583-595, 1998.

Currie, W. S. and Aber, J. D.: Modeling leaching as a decomposition process in humid, montane forets, Ecology, 78, 1844-1860, 1997.

Cusack, D. F., Chou, W. W., Yang, W. H., Harmon, M. E., Silver, W. L., and the LIDET team: Controls on long-term root and leaf litter decomposition in neotropical forests, Glob. Change 20 Biol., 15, 1339-1355, 2009.

Djego, J. G. M.: Phytosociologie de la végétation de sous-bois et impact écologique des plantations forestières sur la diversité floristique au sud et au centre du Bénin, Thèse de doctorat, Université d'Abomey-Calavi, 2006.

Effland, M. J.: Modified procedures to determine acid-insoluble lignin in wood and pulp, Tappi, $25 \quad 60,143-144,1977$.

Ellison, A. M.: Bayesian inference in ecology, Ecol. Lett., 7, 509-520, 2004.

FAO: Global Forest Resources Assessment, Main Report, FAO Forestry Paper 163, Rome, 2010.

FAO/IIASA/ISRIC/ISSCAS/JRC: Harmonized World Soil Database (version 1.0), FAO, IIASA, Rome, Italy and Laxenburg, Austria, 42, 2008.

Gholz, H. L., Wedin, D. A., Smitherman, S. M., Harmon, M. E., and Parton, W. J.: Long-term dynamics of pine and hardwood litter in contrasting environments: toward a global model of decomposition, Glob. Change Biol., 6, 751-765, 2000.
GMDD

6, 3003-3032, 2013

Soil carbon

modeling in tropical

forests

G. H. S. Guendehou et al.

Title Page

Abstract

Introduction

Conclusions

Tables

References

Figures

14

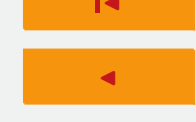

$\rightarrow 1$

Back

Close

Full Screen / Esc

Printer-friendly Version

Interactive Discussion 
Goma-Tchimbakala, J. and Bernhard-Reversat, F.: Comparison of litter dynamics in three plantations of an indigenous timber-tree species (Terminalia superba) and a natural tropical forest in Mayombe, Congo, Forest Ecol. Manag., 229, 304-313, 2006.

Guendehou, G. H., Liski, J., Tuomi, M., Moudachirou, M., Sinsin, B., and Mäkipää, R.: Decom5 position and changes in chemical composition of leaf litter of five dominant tree species in a West African tropical forest, Tropical Ecology, 55, accepted, 2014.

Haario, H., Saksman, E., and Tamminen, J.: An adaptive Metropolis algorithm, Bernoulli, 7, 223-242, 2001.

Hastings, W.: Monte Carlo sampling method using Markov chains and their applications, Biometrika, 57, 97-109, 1970.

Henry, M., Valentini, R., and Bernoux, M.: Soil carbon stocks in ecoregions of Africa, Biogeosciences Discuss., 6, 797-823, doi:10.5194/bgd-6-797-2009, 2009.

Intergovernmental Panel on Climate Change (IPCC): Good Practice Guidance for Land Use, Land-Use Change and Forestry, edited by: Penman, J., Gytarsky, M., Hiraishi, T., Krug, T., Kruger, D., Pipatti, R., Buendia, L., Miwa, K., Ngara, T., Tanabe, K., and Wagner, F., IPCC/IGES, Hayama, Japan, 2003.

Intergovernmental Panel on Climate Change (IPCC): Guidelines for National Greenhouse Gas Inventories, edited by: Eggleston, S., Buendia, L., Miwa, K., Ngara, T., and Tanabe, K., IPCC/IGES, Hayama, Japan, 2006.

20 Karhu, K., Fritze, H., Tuomi, M., Vanhala, P., Spetz, P., Kitunen, V., and Liski, J.: Temperature sensitivity of organic matter decomposition in two boreal forest soil profiles, Soil Biol. Biochem., 42, 72-82, 2010.

Krull, E. S., Bestland, E. A., and Gates, W. P.: Soil organic matter decomposition and turnover in a tropical ultisol: evidence from $\delta^{13} \mathrm{C}, \delta^{15} \mathrm{~N}$ and geochemistry, Radiocarbon, 44, 93-112, 252002.

Küppers, K., Sturm, H. J., Emrich, A. and Horst, M. A.: Evaluation écologique intégrée de la forêt naturelle de la Lama en République du Bénin, Rapport sur la flore et la sylviculture, Elaboré pour le compte du projet Promotion de l'économie forestière et du bois, PN 95.66.647, Office National du Bois, Kfw GTZ, 1998.

30 Kurz, W. A. and Apps, J. M.: A 70-year retrospective analysis of carbon fluxes in the Canadian forest sector, J. Appl. Ecol., 9, 526-547, 1999.
GMDD

6, 3003-3032, 2013

Soil carbon

modeling in tropical

forests

G. H. S. Guendehou et al.

Title Page

Abstract

Introduction

Conclusions

References

Tables

Figures

14

$\rightarrow 1$

4

Back

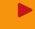

Close

Printer-friendly Version

Interactive Discussion 
Lavelle, P., Blanchart, E., Martin, A., Spain, A., Toutain, F., Barois, I., and Schaefer, R.: A hierarchical model for decomposition in terrestrial ecosystems: application to soils of the humid tropics, Biotropica, 25, 130-150, 1993.

Liski, J., Nissinen, A., Erhardt, M., and Taskinen, O.: Climatic effects on litter decomposition from arctic tundra to tropical rainforests, Glob. Change Biol., 9, 575-584, 2003.

Liski, J., Palosuo, T., Peltoniemi, M., and Sievänen, R.: Carbon and decomposition model Yasso for forest soils, Ecol. Model., 189, 168-182, 2005.

Loranger, G., Ponge, J. F., Imbert, D., and Lavelle, P.: Leaf decomposition in two semi-evergreen tropical forests: influence of litter quality, Biol. Fert. Soils, 35, 247-252, 2002.

10 Malve, O., Laine, M., Haario, H., Kirkkala, T., and Sarvala, J.: Bayesian modelling of algal mass occurrences - using adaptive MCMC methods with a lake water quality model, Environ. Modell. Softw., 22, 966-977, 2007.

Manu, A., Bationo, A., and Geiger, S. C.: Fertility status of selected millet producing soils of West Africa with emphasis on phosphorus, Soil Sci., 152, 315-320, 1991.

Meentemeyer, V.: Macroclimate and lignin control of litter decomposition rates, Ecology, 59, 465-472, 1978.

Meng, J., Lu, Y., Lei, X., and Liu, G.: Structure and floristics of tropical forests and their implications for restoration of degraded forests of China's Hainan Island, Tropical Ecology, 52, 177-191, 2011.

20 Metropolis, N., Rosenbluth, A. W., Rosenbluth, M. N., Teller, A. H., and Teller, E.: Equations of state calculations by fast computing machines, J. Chem. Phys., 21, 1087-1092, 1953.

Mondjannagni, A.: Contribution à l'étude des paysages végétaux du Bas Dahomey, Annales Université d'Abidjan GI, Fasc. 2, Abidjan, 1969.

Nagel, P., Sinsin, B., and Peveling, R.: Conservation of biodiversity in a relic forest in Benin - an overview, Regio Basiliensis 45/2, S, 125-137, 2004.

Palosuo, T., Foereid, B., Svensson, M., Shurpali, N., Lehtonen, A., Herbst, M., Linkosalo, T., Ortiz, C., Todorovic, G. R., Marcinkonis, S., Li, C., and Jandl, R.: A multi-model comparison of soil carbon assessment of a coniferous forest stand, Environ. Modell. Softw., 35, 38-49, 2012.

30 Paradis, G. and Houngnon, P.: La végétation de l'aire classée de la Lama dans la mosaïque forêt-savane du Sud-Bénin, Bulletin du Muséum national d'histoire naturelle, 3ème série, Botanique, 34, 169-198, 1977.

Soil carbon

modeling in tropical

forests

G. H. S. Guendehou et al.

Title Page

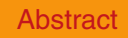

Introduction

Conclusions

Tables

References

Figures

14

4

Back

Close

\section{Full Screen / Esc}

Printer-friendly Version

Interactive Discussion 
Parton, W., Silver, W. L., Burke, I. C., Grassens, L., Harmon, M. E., Currie, W. S., King, J. Y., Adair, E. C., Brandt, L. A., Hart, S. C., and Fasth, B.: Global-scale similarities in nitrogen release patterns during long-term decomposition, Science, 315, 361-364, 2007.

Peltoniemi, M., Thürig, E., Ogle, S., Palosuo, T., Schrumpf, M., Wutzler, T., Butterbach-Bahl, K., 5 Chertov, O., Komarov, A., Mikhailov, A., Gärdenäs, A., Perry, C., Liski, J., Smith, P., and Mäkipää, R.: Models in country scale carbon accounting of forest soils, Silva Fenn., 41, 575602, 2007.

Prudencio, C. Y.: Ring management of soils and crops in the West African semi-arid tropics: the case of the mossi farming system in Burkina Faso, Agr. Ecosyst. Environ., 47, 237-264, 101993

Sierra, C. A., Müller, M., and Trumbore, S. E.: Models of soil organic matter decomposition: the SoilR package, version 1.0, Geosci. Model Dev., 5, 1045-1060, doi:10.5194/gmd-5-10452012, 2012.

Six, J., Feller, C., Denef, K., Ogle, S. M., de Moraes, S. A. J. C., and Albrecht, A.: Soil or15 ganic matter, biota and aggregation in temperate and tropical soils - effects of no-tillage, Agronomie, 22, 755-775, 2002.

Swift, M. J. and Anderson, J. M.: Decomposition, in: Tropical Rainforest Ecosystems, Biogeographical and Ecological Studies, Ecosystems of the World, 14B, edited by: Lieth, H. and Werger, M. J. A., Elsevier, Amsterdam, 547-569, 1989.

20 Tian, G., Kang, B. T., and Brussaard, L.: Biological effects of plant residues with contrasting chemical composition under humid tropical conditions - decomposition and nutrient release, Soil Biol. Biochem., 24, 1051-1060, 1992.

Trofymow, J. A. and the CIDET Working Group: The Canadian Intersite Decomposition Experiment (CIDET), Project and site establishment report, Information report BC-X-378, Pacific Forestry Centre, Victoria, Canada, 1998.

Tuomi, M., Thum, T., Jarvinen, H., Fronzek, S., Berg, B., Harmon, M., Trofymow, J. A., Sevanto, S., and Liski, J.: Leaf litter decomposition - estimates of global variability based on Yasso07 model, Ecol. Model., 220, 3362-3371, 2009.

Tuomi, M., Laiho, R., Repo, A., and Liski, J.: Wood decomposition model for boreal forests, Ecol. Model., 222, 709-718, 2011 a.

Tuomi, M., Rasinmaki, J., Repo, A., Vanhala, P., and Liski, J.: Soil carbon model Yasso07 graphical user interface, Environ. Modell. Softw., 26, 1358-1362, 2011b.
GMDD

6, 3003-3032, 2013

Soil carbon

modeling in tropical

forests

G. H. S. Guendehou et al.

Title Page

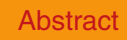

Introduction

Conclusions

References

Tables

Figures

14

$\rightarrow 1$

4

Back

Close

Printer-friendly Version

Interactive Discussion 
Tynsong, H. and Tiwari, B. K.: Diversity and population characteristics of woody species in natural forests and arecanut agroforests of south Meghalaya, Northest India, Tropical Ecology, 52, 243-252, 2011.

UNFCCC: Decision 2/CP.13, Reducing Emissions from deforestation in developing countries: approaches to simulate action, FCCC/CP/2007/6/Add.1, 2008.

UNFCCC: Decision 1/CP.16, The Cancun agreements: Outcome of the work of the Ad Hoc working group on long-term cooperative action under the Convention, FCCC/CP/2010/7/Add.1, 2010.

Volkoff, B., Faure, P., Dubroeucq, D., and Viennot, M.: Estimation des stocks de carbone des sols du Bénin, Etude et gestion des sols, 6, 115-130, 1999.

von Bothmer, K. H., Moumouni, A. M., and Patinvoh, P.: Plan Directeur de la Forêt Classée de la Lama, Projet de développement de l'économie foresti'ere et production de bois, Projet GTZ No. 79.2038.2.01-200, 1986.

Soil carbon

modeling in tropical

forests

G. H. S. Guendehou et al.

Title Page

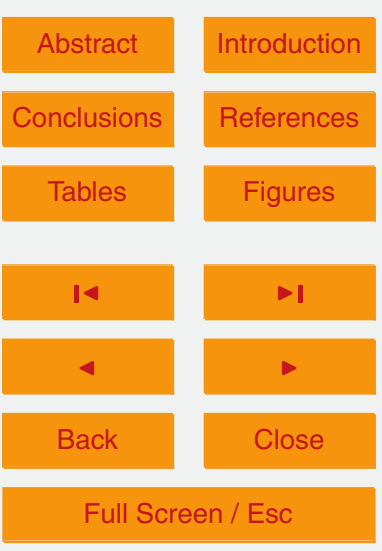

Printer-friendly Version

Interactive Discussion 
Table 1. Monthly climatic data recorded during the litterbag experiment in 2010 by the meteorological stations Bohicon (for temperature) and Toffo (for precipitation) closest to the Lama forest.

\begin{tabular}{lcc}
\hline Month & $\begin{array}{c}\text { Temperature } \\
\left({ }^{\circ} \mathrm{C}\right)\end{array}$ & $\begin{array}{c}\text { Precipitation } \\
(\mathrm{mm})\end{array}$ \\
\hline Feb & 31.4 & 80.1 \\
Mar & 30.6 & 192.4 \\
Apr & 30.2 & 100.3 \\
May & 29.0 & 157.1 \\
Jun & 28.1 & 90.1 \\
Jul & 26.6 & 149.0 \\
\hline
\end{tabular}

GMDD

6, 3003-3032, 2013

Soil carbon

modeling in tropical

forests

G. H. S. Guendehou et al.

Title Page

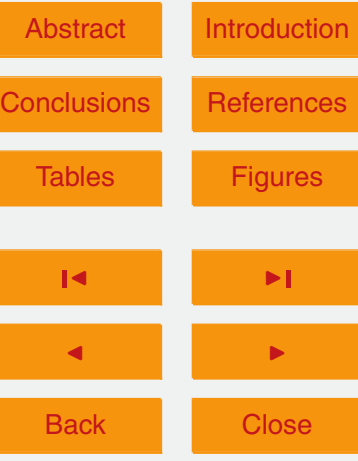

Full Screen / Esc

Printer-friendly Version

Interactive Discussion 
Table 2. Parameter values of the original calibration of Yasso07 and of the parameterization of Yasso07 using only data from Benin and thereafter all data (global data and data from Benin together).

\begin{tabular}{|c|c|c|c|c|c|c|c|c|}
\hline \multirow{2}{*}{ Parameter } & \multirow{2}{*}{ Unit } & \multicolumn{2}{|c|}{ Benin data } & \multicolumn{2}{|c|}{ All data } & \multicolumn{2}{|c|}{ Original calibration* } & \multirow{2}{*}{ Interpretation } \\
\hline & & MAP & $95 \% \mathrm{Cl}$ & MAP & $95 \% \mathrm{Cl}$ & MAP & $95 \% \mathrm{Cl}$ & \\
\hline$\alpha_{\mathrm{A}}$ & $\mathrm{yr}^{-1}$ & 3.97 & \pm 0.74 & 0.39 & \pm 0.03 & 0.72 & \pm 0.09 & $d_{\text {rate }}$ of $\mathrm{A}$ \\
\hline$\alpha_{w}$ & $\mathrm{yr}^{-1}$ & 20.55 & \pm 3.10 & 4.54 & \pm 0.30 & 5.9 & \pm 0.8 & $d_{\text {rate }}$ of $\mathrm{W}$ \\
\hline$\alpha_{\mathrm{E}}$ & $\mathrm{yr}^{-1}$ & 17.00 & \pm 3.50 & 0.34 & \pm 0.04 & 0.28 & $+0.07,-0.04$ & $d_{\text {rate }}$ of $E$ \\
\hline$\alpha_{N}$ & $\mathrm{yr}^{-1}$ & 3.57 & \pm 0.50 & 0.13 & \pm 0.02 & 0.031 & $+0.011,-0.004$ & $d_{\text {rate }}$ of $\mathrm{N}$ \\
\hline$p_{1}$ & - & 0.02 & \pm 0.02 & 0.00 & $+0.01,-0.00$ & 0.48 & \pm 0.06 & $m_{\text {flow }}, \mathrm{W} \rightarrow \mathrm{A}$ \\
\hline$p_{2}$ & - & 0.01 & $+0.04,-0.01$ & 0.01 & \pm 0.01 & 0.01 & $+0.15,-0.01$ & $m_{\text {flow }}, \mathrm{E} \rightarrow \mathrm{A}$ \\
\hline$p_{3}$ & - & 0.79 & \pm 0.33 & 0.87 & \pm 0.03 & 0.83 & $+0.16,-0.23$ & $m_{\text {flow }}, \mathrm{N} \rightarrow \mathrm{A}$ \\
\hline$p_{4}$ & - & 0.71 & \pm 0.15 & 0.99 & \pm 0.01 & 0.99 & $+0.01,-0.05$ & $m_{\text {flow }}, \mathrm{A} \rightarrow \mathrm{W}$ \\
\hline$p_{5}$ & - & 0.05 & \pm 0.05 & 0.05 & $+0.01,-0.00$ & 0.00 & $+0.08,-0.00$ & $m_{\text {flow }}, \mathrm{E} \rightarrow \mathrm{W}$ \\
\hline$p_{6}$ & - & 0.04 & $+0.16,-0.04$ & 0.00 & $+0.01,-0.00$ & 0.01 & $+0.20,-0.01$ & $m_{\text {flow }}, \mathrm{N} \rightarrow \mathrm{W}$ \\
\hline$p_{7}$ & - & 0.05 & \pm 0.05 & 0.00 & $+0.01,-0.00$ & 0.00 & $+0.01,-0.00$ & $m_{\text {flow }}, \mathrm{A} \rightarrow \mathrm{E}$ \\
\hline$p_{8}$ & - & 0.06 & $+0.07,-0.06$ & 0.00 & $+0.01,-0.00$ & 0.00 & $+0.01,-0.00$ & $m_{\text {flow }}, \mathrm{W} \rightarrow \mathrm{E}$ \\
\hline$p_{9}$ & - & 0.13 & \pm 0.08 & 0.133 & \pm 0.03 & 0.02 & $+0.23,-0.02$ & $m_{\text {flow }}, \mathrm{N} \rightarrow \mathrm{E}$ \\
\hline$p_{10}$ & - & 0.01 & $+0.04,-0.01$ & 0.01 & \pm 0.01 & 0.00 & $+0.01,-0.00$ & $m_{\text {flow }}, \mathrm{A} \rightarrow \mathrm{N}$ \\
\hline$p_{11}$ & - & 0.02 & $+0.05,-0.02$ & 0.19 & \pm 0.01 & 0.02 & \pm 0.02 & $m_{\text {flow }}, \mathrm{W} \rightarrow \mathrm{N}$ \\
\hline$p_{12}$ & - & 0.88 & \pm 0.11 & 0.44 & \pm 0.01 & 0.95 & $+0.05,-0.16$ & $m_{\text {flow }}, \mathrm{E} \rightarrow \mathrm{N}$ \\
\hline$\beta_{1}$ & $10^{-2}{ }^{\circ} \mathrm{C}^{-1}$ & 0.087 & $+0.01,-0.00$ & 0.069 & \pm 0.01 & 0.095 & \pm 0.02 & $T_{\text {dependence }}$ \\
\hline$\beta_{2}$ & $10^{-3}{ }^{\circ} \mathrm{C}^{-2}$ & -0.0029 & $+0.01,-0.00$ & -0.00050 & 0.001 & -0.0014 & $+0.0006,-0.0009$ & $T_{\text {dependence }}$ \\
\hline$\gamma$ & $m^{-1}$ & -2.500 & \pm 0.05 & -0.939 & \pm 0.09 & -1.21 & \pm 0.14 & $P_{\text {dependence }}$ \\
\hline$\omega_{\mathrm{E}}$ & $\mathrm{yr}^{-1} \mathrm{~m}^{-1}$ & - & 0.005 & -0.2008 & \pm 0.01 & -0.151 & \pm 0.008 & $P_{\text {leaching }}$ Europe \\
\hline$\omega_{\mathrm{A}}$ & $\mathrm{yr}^{-1} \mathrm{~m}^{-1}$ & - & $+0.01,-0.00$ & -0.0006 & \pm 0.01 & 0.000 & $+0.0,-0.002$ & $P_{\text {leaching }}$ America \\
\hline$\omega_{\mathrm{B}}$ & $\mathrm{yr}^{-1} \mathrm{~m}^{-1}$ & -0.061 & \pm 0.19 & -0.943 & \pm 0.04 & - & - & $P_{\text {leaching }}$ Benin \\
\hline
\end{tabular}

GMDD

6, 3003-3032, 2013

Soil carbon

modeling in tropical

forests

G. H. S. Guendehou et al.

Title Page

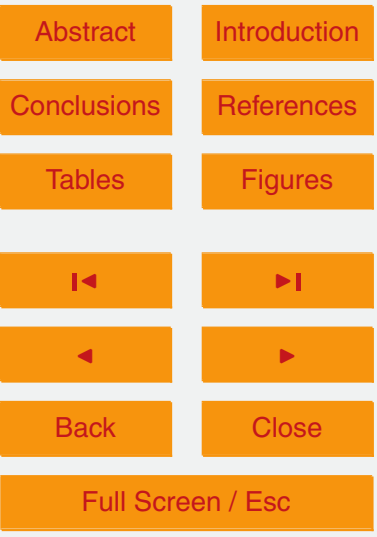

Printer-friendly Version

Interactive Discussion 


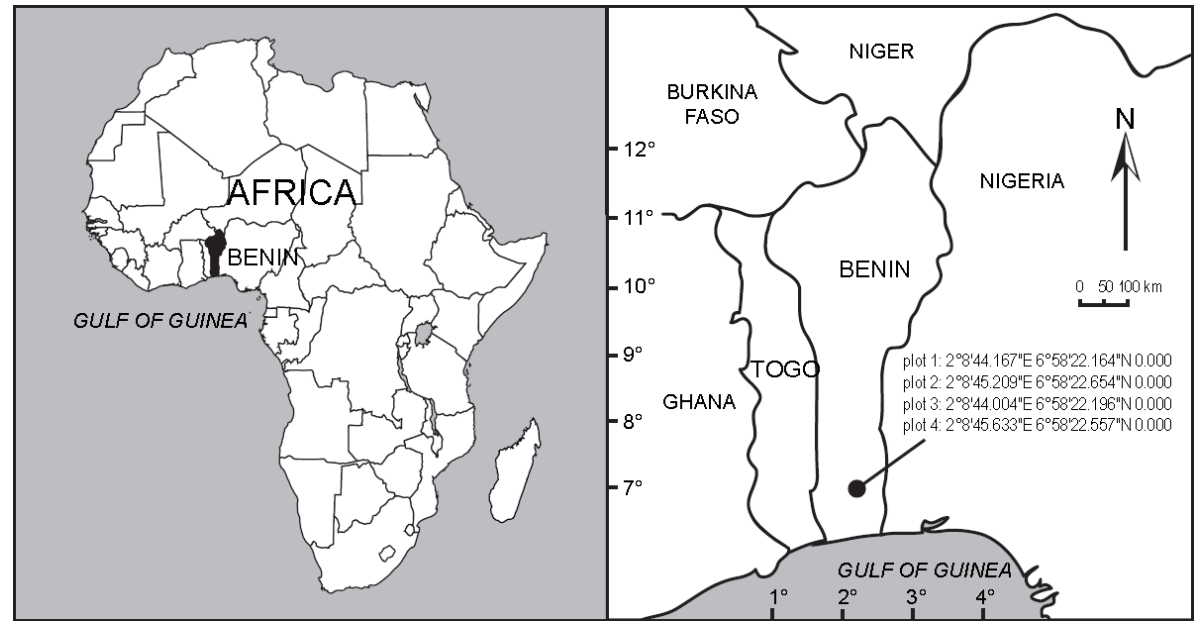

Fig. 1. Location of the study area in Benin.

\section{GMDD}

\section{6, 3003-3032, 2013}

\section{Soil carbon modeling in tropical forests}

\section{G. H. S. Guendehou et al.}

\section{Title Page}

\section{Abstract}

\section{Introduction}

Conclusions

References

Tables

\section{Figures}

14

4

Back

Close

\section{Full Screen / Esc}

Printer-friendly Version

Interactive Discussion 


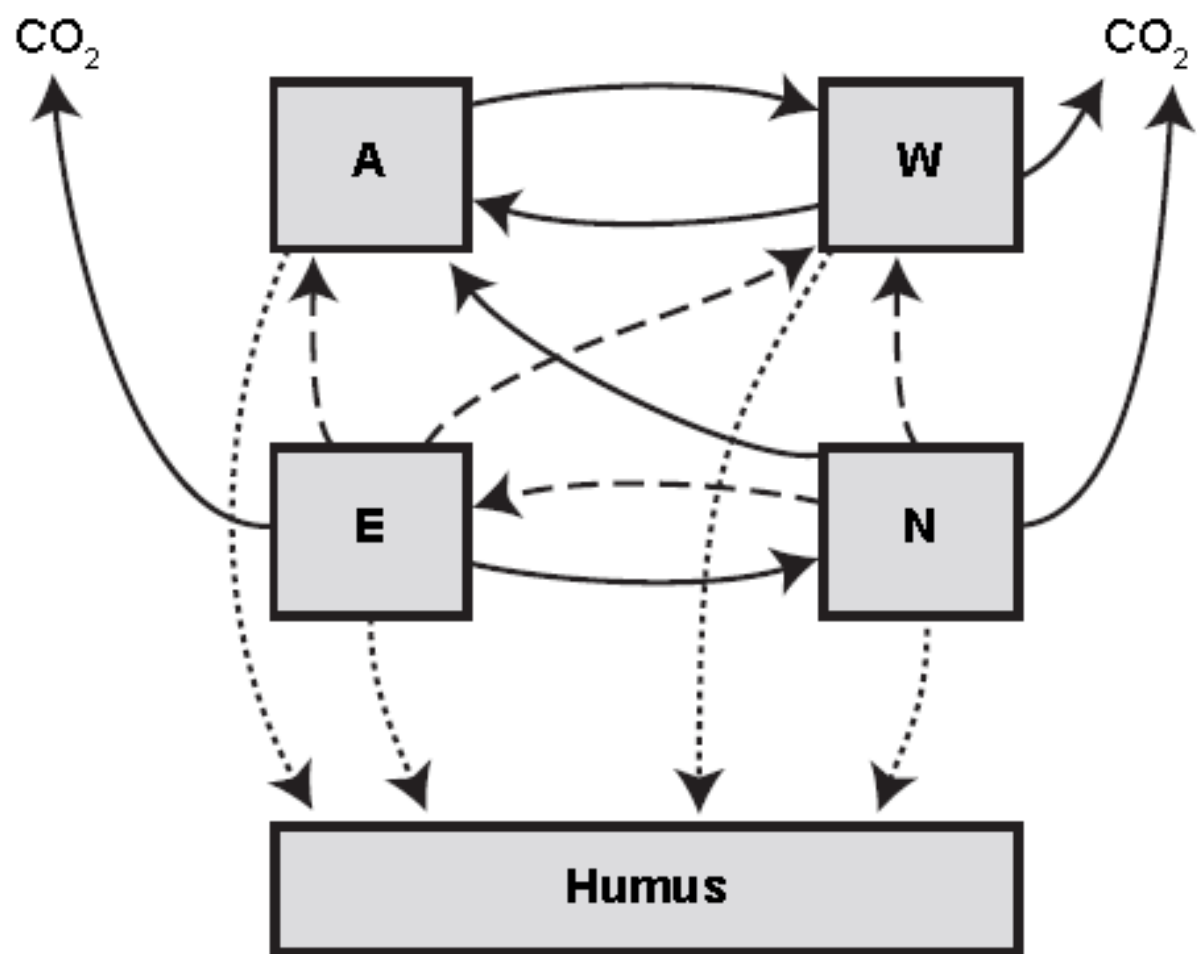

Fig. 2. Flow diagram of the model Yasso07 and the relative magnitudes of each mass flow between labile compound groups of organic carbon and more recalcitrant humus; acidhydrolysable $(A)$, water-soluble $(W)$, ethanol-soluble $(E)$, and compounds neither soluble nor hydrolysable $(\mathrm{N})$. The carbon flows whose magnitudes differ statistically ( $95 \%$ confidence) from zero (solid arrows) between and out of the A, W, E, and N fractions (square boxes); the small flows (dotted arrows) into humus (bottom box), each approximately $0.5 \%$; and the mass flows (dashed arrows) whose maximum a posteriori (MAP) estimates were indistinguishable from zero but whose $95 \%$ Bayesian confidence interval was broader than 0.05 (Tuomi et al., 2011b).

Soil carbon

modeling in tropical

forests

G. H. S. Guendehou et al.

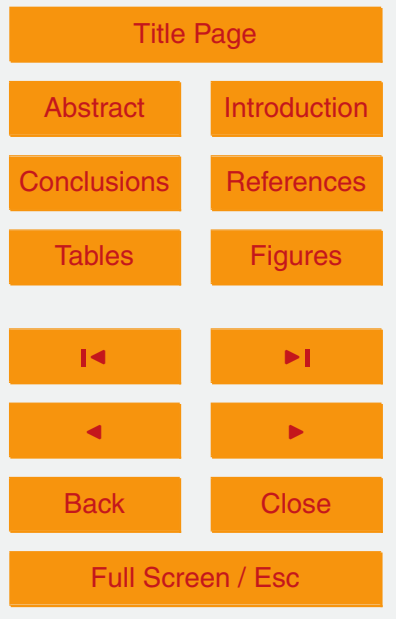

Printer-friendly Version

Interactive Discussion

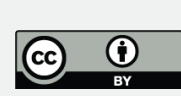



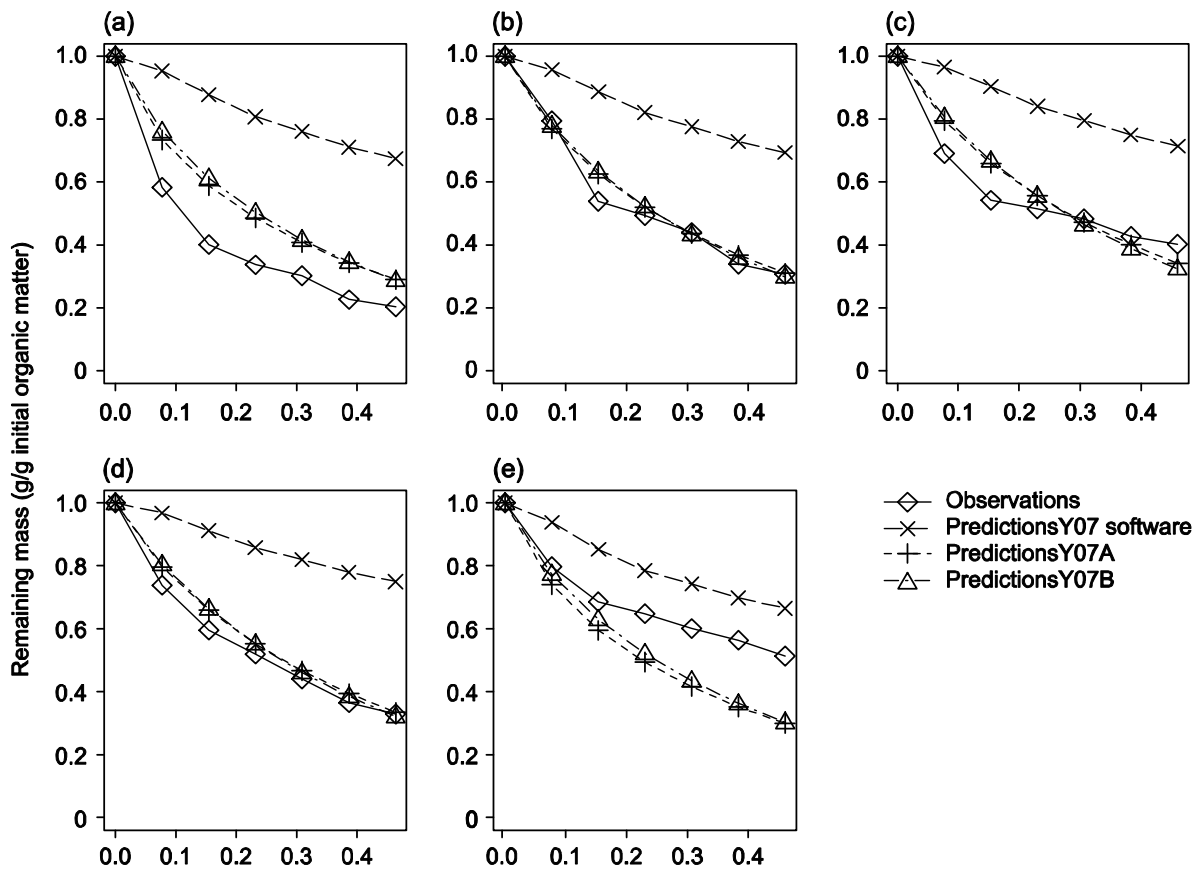

6, 3003-3032, 2013

(e)

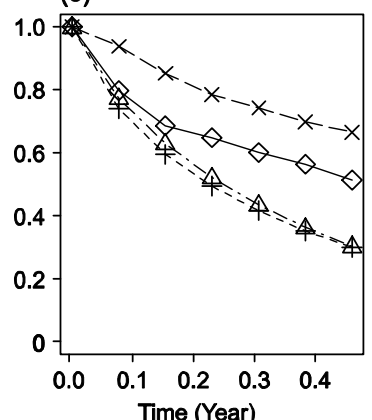
$\vartheta$ Observations
$\rightarrow$ PredictionsY07 software
- - PredictionsY07A
$-\triangle$ PredictionsY07B

Fig. 3. Comparison of the observations on total remaining mass with the predictions from the Yasso07 software, a Yasso07 version resulting from parameterization using the global and Benin data together (Y07A), and a Yasso07 version parameterized using only data from Benin (Y07B), for A. africana (a), A. leiocarpa (b), C. pentandra (c), D. guineense (d) and D. mespiliformis (e).

Soil carbon

modeling in tropical

forests

G. H. S. Guendehou et al.

Title Page

Abstract

Introduction

Conclusions

References

Tables

Figures

14

$>$ I

4

Back

Close

\section{Full Screen / Esc}

Printer-friendly Version

Interactive Discussion 

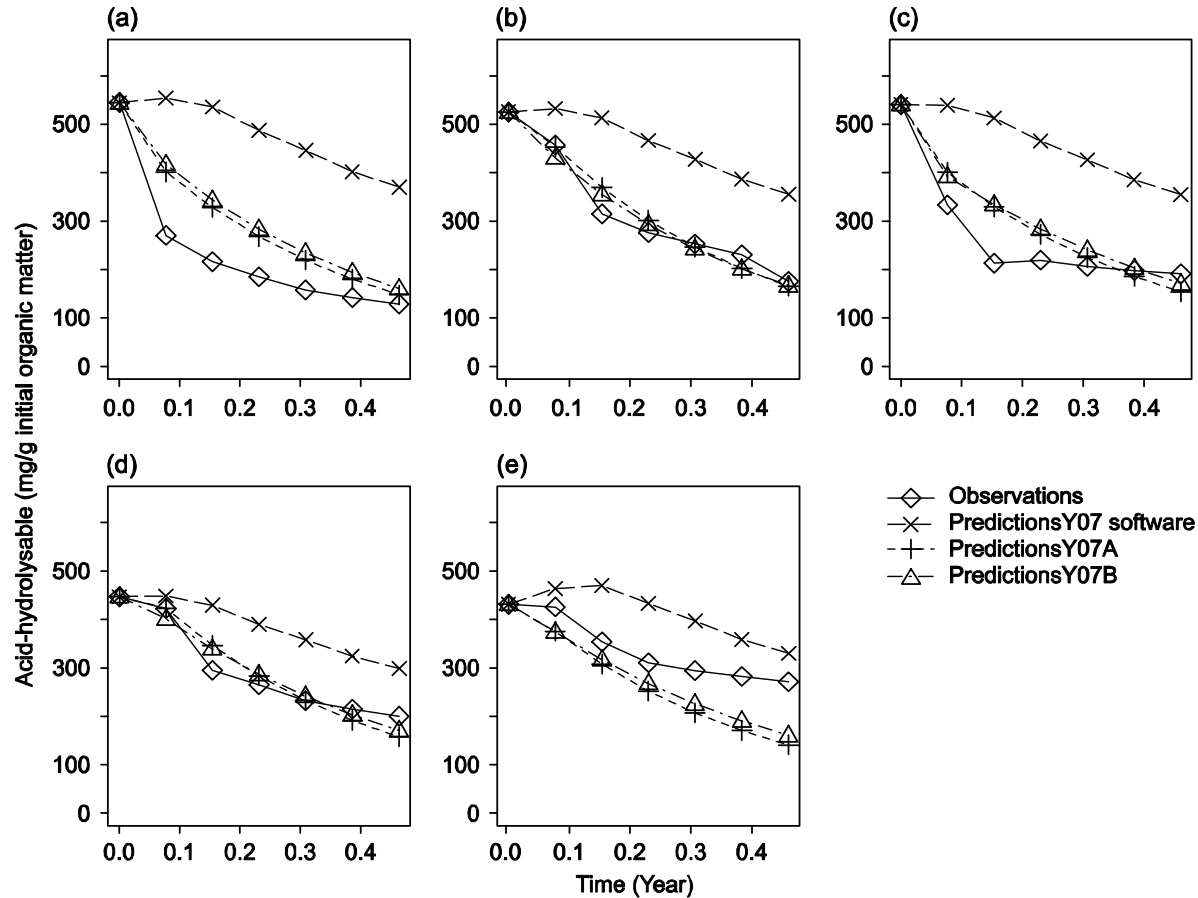

$$
\begin{aligned}
& - \text { Observations } \\
& -\times \text { PredictionsY07 software } \\
& -+- \text { PredictionsY07A } \\
& -\triangle-\text { PredictionsY07B }
\end{aligned}
$$

Fig. 4. Comparison of the observations on the remaining mass of acid-hydrolysable compounds (A) with the predictions from the Yasso07 software, a Yasso07 version resulting from parameterization using the global and Benin data together (Y07A), and a Yasso07 version parameterized using only data from Benin (Y07B), for $A$. africana (a), A. leiocarpa (b), C. pentandra (c), $D$. guineense (d) and $D$. mespiliformis (e).

Soil carbon

modeling in tropical forests

G. H. S. Guendehou et al. Title Page

\section{Abstract} Introduction

Conclusions References

Tables Figures

14 >I

4

Back

Close

\section{Full Screen / Esc}

Printer-friendly Version

Interactive Discussion 

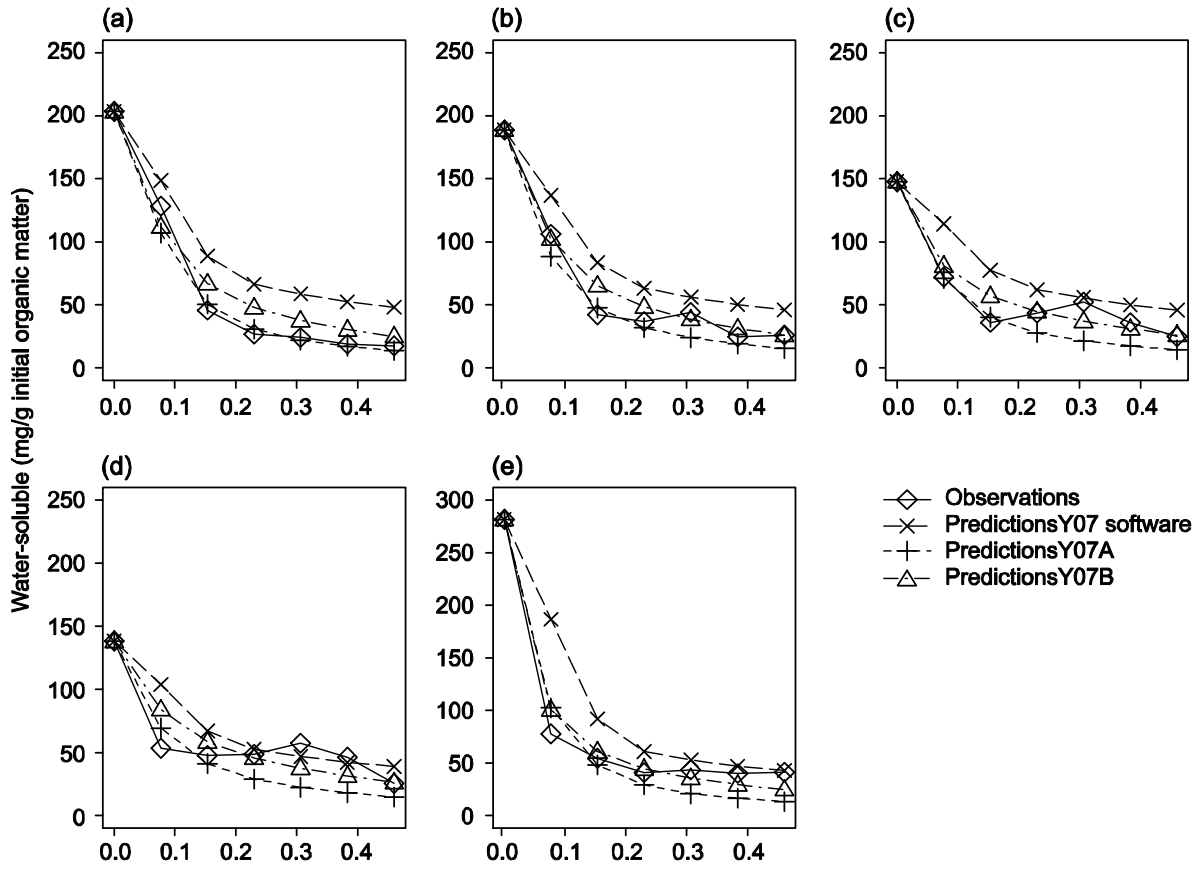

GMDD

6, 3003-3032, 2013

Soil carbon

modeling in tropical

forests

G. H. S. Guendehou et al.

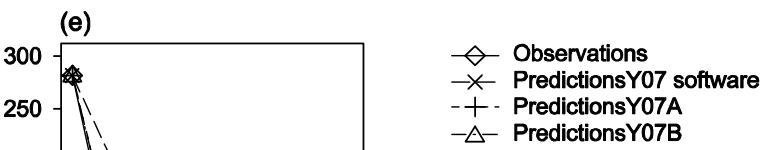

Title Page

Abstract

Introduction

- - PredictionsY07A

Fig. 5. Comparison of the observations on the remaining mass of water-soluble compounds (W) with the predictions from the Yasso07 software, a Yasso07 version resulting from parameterization using the global and Benin data together (Y07A), and a Yasso07 version parameterized using only data from Benin (Y07B), for A. africana (a), A. leiocarpa (b), C. pentandra (c), D. guineense (d) and D. mespiliformis (e).

Conclusions

References

Tables

Figures

14

4

Back

Close

Full Screen / Esc

Printer-friendly Version

Interactive Discussion 
(a)
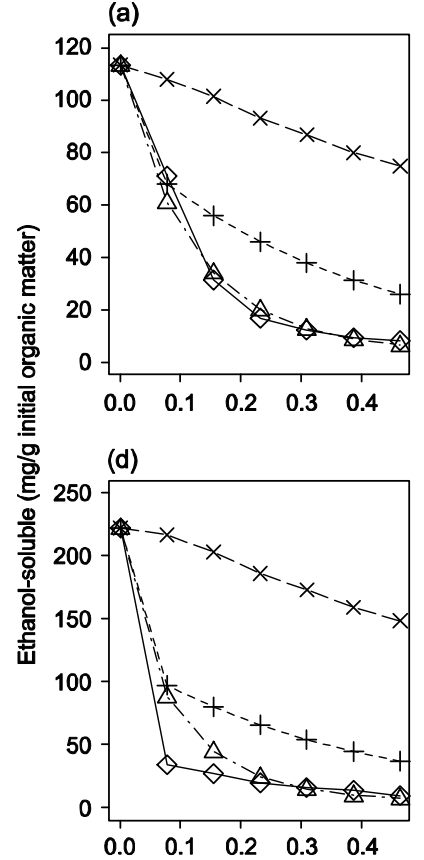

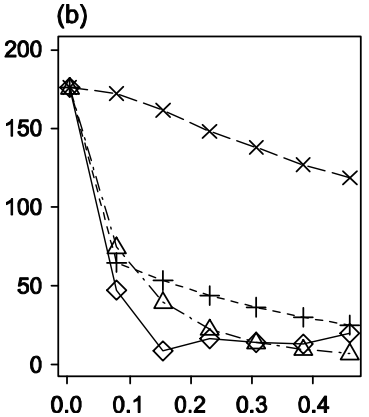

(c)
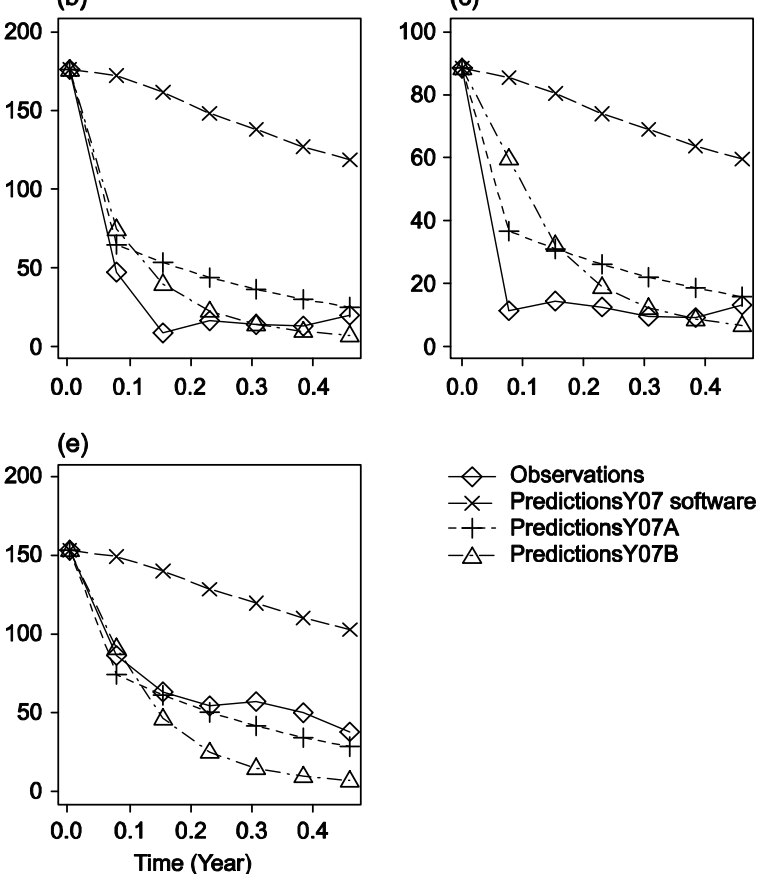

GMDD

6, 3003-3032, 2013

Soil carbon

modeling in tropical

forests

G. H. S. Guendehou et al.

\section{Title Page}

Abstract

Introduction

- Predictions $Y 07$ software

-+- PredictionsY07A

$-\triangle$ - PredictionsY07B

4

\section{Full Screen / Esc} (E) with the predictions from the Yasso07 software, a Yasso07 version resulting from parameterization using the global and Benin data together (Y07A), and a Yasso07 version parameterized using only data from Benin (Y07B), for A. africana (a), A. leiocarpa (b), C. pentandra (c), D. guineense (d) and $D$. mespiliformis (e).

Printer-friendly Version

Interactive Discussion 

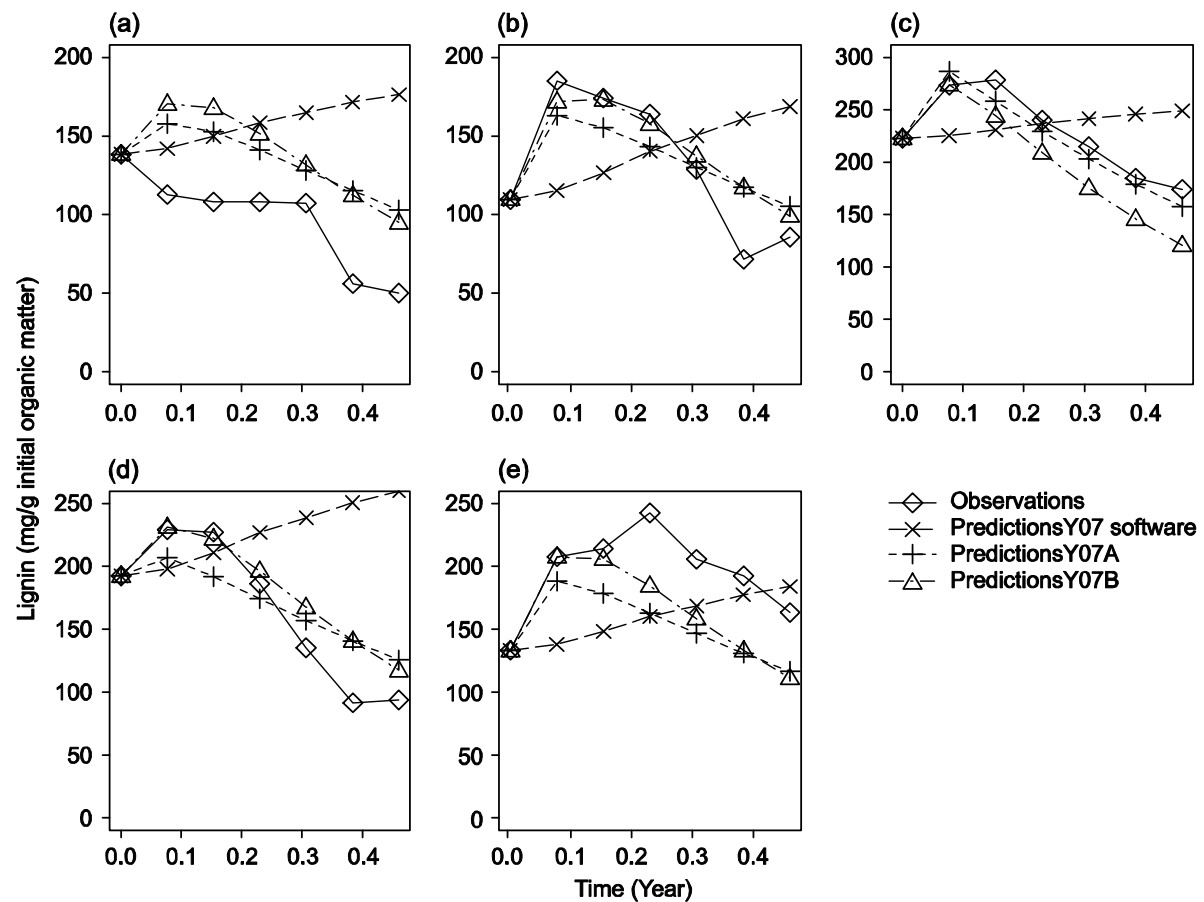

Title Page

Abstract

Introduction

-A- PredictionsY07A

Conclusions

References

Tables

Figures

14

$\rightarrow 1$

4

Back

Close

\section{Full Screen / Esc}

Printer-friendly Version and $D$. mespiliformis (e). 